\title{
UNIVERSITY AUTONOMY AND ACADEMIC FREEDOM IN LATIN AMERICA
}

\author{
LUIGI Einaud**
}

\section{INTRODUCTION}

Latin American universities have surprisingly little in common with universities in the United States. They have their own distinctive traditions, operate in a different environment, and have functions and prerogatives not normally associated with institutions of higher learning in this country. Unlike the Constitution of the United States, which makes no reference to education, all Latin American constitutions make provision for education, sometimes at great length. The tone of higher education in the United States has, at least until recently, been set predominantly by private institutions; the opposite has been the case in Latin America ever since the founding of the first "Royal and Pontifical" universities in Peru and Mexico in I55I. In the United States, discussions of academic freedom have often centered on educational considerations, primarily in terms of the role of teachers as educators rather than as citizens, and have dealt only very secondarily with the role of students. In Latin America, freedom of instruction (libertad de catedra) has been but a small part of the controversy centering on university autonomy, which has encompassed students as much as professors, and social and political issues as well as educational ones. During the twentieth century, major questions have been raised, usually with little agreement, about the function of universities in changing societies. The issue of university autonomy has thus been combined with, and complicated further by, that of university reform.

The modern history of the Latin American university is thus largely the story of the effort to make higher education relevant to Latin America and its problems. This struggle, waged in the name of university autonomy and reform, has involved the simultaneous affirmation and rejection of past university traditions, and, since few could agree on either the needs or the means by which the universities could best fulfill them, it has also projected the university into the political arena. This in turn has created new political traditions from which most Latin American universities can today escape only with difficulty even under the best of circum-

* B.A. I957, Harvard College. Ph.D. Candidate, Harvard University. Teaching Fellow and Tutor in Government, Harvard University, 1960-6I; Instructor in Government, Wesleyan University, I96I-62; Staff Member, Social Science Department, The RAND Corporation, Santa Monica, California, since June rg62.

The author wishes to express his indebtedness to the U.S. National Student Association, which introduced him to the problems discussed here by sending him to Latin America as its representative in 1955 and 1956. The views expressed in this paper are, however, entirely those of the author. They should also not be interpreted as reflecting the views of The RAND Corporation or the official opinion or policy of any of its governmental or private research sponsors.

Unless otherwise indicated, all translations are the author's. 
stances. How and why this came about, and the effect of the political role of the university on its freedom and mission, is the topic of this paper. ${ }^{1}$

We, men of a free Republic, have just broken the last chains which in the twentieth century still bound us to monarchic and monastic domination. . . . The Universities haveuntil now been the secular haven of the mediocre, the reward of the ignorant, a shelter for intellectual invalids, and-still worse-places in which tyranny and insensibility in all their forms can always make their voices heard. The Universities have therefore become faithful images of our decadent societies, sad spectacles of senile immobility. ... We have rebelled against a form of administration, against a system of education, and against a concept of authority. ... . We are tired of supporting tyrants . . . and cannot be denied the right to participate in the government of our own institution. ${ }^{2}$

The university reform movement is normally traced to this curious mixture of education and politics infused with rebellious idealism. The students of Cordoba. did in fact have serious grievances, educational and otherwise, and the speed with which the movement spread indicated that their feelings were shared by some of the other "free men of South America" to whom the proclamation was addressed." The specific educational complaints were many: poor instruction, almost exclusive emphasis on learning by rote from obsolete texts, inadequate libraries, absence of practical training, and teaching methods "characterized by a narrow dogmatism which contributes to the insulation of the university from science and modern. learning." In his message of support to the students, Alfredo Palacios commented that it was necessary to eradicate from Latin America the ideas expressed by the influential professor at the University of Unreason in Samuel Butler's Erehwon: "Our mission is not to help students to think for themselves. . . . Our duty is to. make them think as we do, or at least as we find it convenient to say we think."4.

The operational basis for the introduction of reforms was to be student participa-

1 The Latin American experience, particularly when contrasted with our own, has sufficient distinctiveness to justify this generalized treatment, although it will obviously not apply equally everywhere. Major exceptions will be noted.

${ }^{2}$ La Juventud Argentina de Cordoba a los Hombres Libres de Subamerica (Manifiesto del 21 de junio de 19r8). This document is reproduced in two important recent collections of documents on the university reform movement: Coordinating SECRETARIAT OF THE INTERNational Student ConfERENCE (COSEC), La Reforma Universitaria en AMerica Latina (published by COSEC, Box 36, Leiden, Holland, 1960) (also available in poor English and French editions); and Federacion Universitaria de Buenos Aires (FUBA), La Reforma Universitaria, I9I8-I958 (Buenos Aires, 1959). Ari interesting commentary on the reform movement will be found in Harrison, The Confrontation with the Political University, in R. N. BuRr (Ed.), Latin AMerica's Nationalistic Revolutions, 334 Annals 74-83 (March I96r).

${ }^{3}$ The impact of the reform movement had been felt throughout Latin America by I930. See del Mazo, Lo que significa la Reforma, in COSEC, LA REForma Universitaria en AMaricana LATINa, op. cit. supra note 2 , at $17-44$.

- Alfredo L. Palacios, Mensaje a la Juventud Iberoamericana (Igi8). Palacios, unlike some of his followers, was also a respecter of intellectual freedom. Cf. his World War I support of Bertrand Russell and praise for H. G. Wells' defense of the right of Eugene Debs to appear at Harvard under the auspices of the student council. IA UnIVERsidad Nueva 66-67 (1925). In March $x 962$, at the age of 82, Palacios was still sticking to his principles, and resigned as Senator from Buenos Aires to protest the military coup against Frondizi. 
tion in the administrative and policy-making organs of the university. This would enable the universities to reform themselves while remaining autonomous, that is, independent of the state, which many reformers considered hostile to their goals. Student participation in the conduct of university affairs was also considered in tune with the pace of modern ideas: the university was to be "democratized." Luis Alberto Sanchez, twice rector of the University of San Marcos, wrote later that those who see in the reform movement "a symptom of chaos or backwardness only reveal their ignorance of the history and the current needs of our Universities."

The demand for drastic changes in the university system, combined with a demand for student participation which was tantamount to a vote of no confidence in the professors, amounted to an intellectual revolution. The rise of the reform movement in fact reflected more than limited educational grievances: it was also a reaction to the political and social atmosphere of the university and to the place of universities in the political order. It was a reaction to the impact of World War I, which symbolized the corruption of Europe, and the consequent need, embodied at a distance in the Russian revolution, of finding new forms of organization and progress. In their rebellion, the students were protesting not only the conception of education as "classics for aristocrats," but that of an elite society as well. Autonomy was a prerequisite for reform of the university, and the reform of the university was in turn the first step toward the reform of the entire society.

The reform of the university was thus linked from the outset with national politics. This was due both to the reformers themselves (Palacios is a Socialist; Sanchez is an Aprista), and to the very concept of the university which they put forth. This concept is best defined in article 143 of the I945 Constitution of Ecuador: "The universities are autonomous ... and will particularly attend to the study and resolution of national problems and the spread of culture among the popular classes." The best characterization of such a view of the universities is that it is a dynamic but inherently contradictory conception which explicitly makes of the university a political institution.

There are at present fewer than one hundred universities in Latin America. Recent years have seen the founding of many new universities, and as indicated in the conclusion, there is something of a qualitative change taking place as a result. Nonetheless, ten countries still have only one university: these are the smaller countries which support a single "national" or state university. ${ }^{6}$ In other countries, those universities not supported directly by the state are mainly Catholic institutions.? Private secular universities are few and, with the exception of Colombia, relatively uninfluential. Although the reform movement is national in scope and universal

¿ Luis Alberto Sanchez, La Universidad Latinoarericana 15 (Guatemala, 1949).

- Costa Rica, the Dominican Republic, El Salvador, Guatemala, Haiti, Honduras, Nicaragua, Panama, Paraguay, and Uruguay. Even in some of these countries, however, there have been recent efforts to develop new specialized institutes or to establish small private universities.

7 The most important Catholic universities are those of Chile and Peru. None was allowed in Argentina prior to I958. One aspect of the reform movement not dealt with in this paper has been its strong anti-clerical flavor. 
in tone and has provided a number of themes relevant to the private universities, its main impact has been on the national universities. These are the most important as well as the most numerous, and it is to them that we now turn.

\section{II}

The writings of the reform movement, an Argentine professor has recently written, contain "nothing but rebellion and protest, utopias, proclamations, and vain words." prevent the adoption, in the great majority of the national universities, of the main goals of the reform movement. The implementation has been uneven, partly as a result of ambiguity in the reform movement itself, and partly because of the ease with which the reform could be adapted to serve partisan political ends.

Autonomy has been recognized, at least verbally, almost everywhere. Sometimes this recognition has been embodied in constitutional provisions, but it is usually to be found in the opening articles of the statutes of the university. The concept itself is deeply rooted in the Latin American university tradition, and goes back to the medieval concept of the university as a guild with special "privileges and exemptions." The statutes of most of the early colonial universities were modeled directly on those of the University of Salamanca in Spain. ${ }^{9}$ After independence, the universities were either nationalized or closed, and it was not until after the turn of the century, and especially after the development of the reform movement, that efforts were made to re-establish effective autonomy.

The least well-established aspect of autonomy is the economic one. Few of the universities have separate endowments apart from the allotment received from the national government. In some cases, efforts have been made to make constitutional provision for the establishment of an independent source of income. These provisions have led to the earmarking of certain tax revenues automatically for the universities, so that the state could directly control neither the quantity of funds nor their use. The penury of the Latin American universities has been such, however, that they have continually had to be at the mercy of the government for increases in funds..$^{10}$

\footnotetext{
${ }^{8}$ Marcos Victoria, in the prologue to Alejandro Dussant, Crisis en IA UnIversidad Argentina 8 (Buenos Aires, AALC, r96r).

- "Although there were often complaints of viceregal interference in the choice of rectors, or in the recommendation of candidates for degrees, the University was one of the few corporations in America that retained any degree of autonomy." Clarence H. Haring, The Spanish EMpire in America 230 (1947). Cf. Julio Jimenez Rueda, Historia Juridica de la Universidad de Mexico, Pait I (Mexico, Facultad de Filosofia y Letras, 1955).

${ }^{10}$ Some indication of relative resources may be gathered by comparing receipts of the University of California in $1958-59, \$ 153.7$ million, with the combined central government receipts of Costa Rica, Panama, and Honduras for 1959 , which came to $\$ 156.7$ million. For political implications, see the tragic debate in July 1960 during which the administration of the University of Havana attempted to defend itself against fidelista student criticisms of its shortcomings by pointing out that the University of Puerto Rico, not a notoriously wealthy institution, had $25 \%$ fewer students but seven times the income. La Untuersida de ia Habana Hacia una Nueva Etapa 3-4 and passim (ig60).
} 
In practice, the autonomy issue has centered on administrative and political issues. A major test of autonomy is the means of selection of the rector. If the rector, who combines the attributes of president and dean at most United States universities, is chosen internally, by the university itself, there is autonomy; otherwise not. In normal experience, of course, such a formal line is often blurred in the course of actual relations with the government, but the formal legal question of selection of the rector has assumed a central position in the public debate.

Some of the elements of this problem can be best seen by looking briefly at some of the developments in Argentina since r945. One of Juan Peron's first actions after being elected president was to intervene the universities by appointing his own supporters to the positions of rector and deans of faculties at the University of Buenos Aires, where much of the opposition to him had been centered. This was followed by the promulgation, in September 1947, of a new university law. ${ }^{11}$ According to article I of the law, the university was granted "technical, educational, and scientific autonomy." But after thus paying lip service to the principle of autonomy, the law provided for the naming of the rector (article xo) and full professors (titulares) (article 46) by the "national executive": Peron.

During the formal act of promulgation of the new law, Peron complained that the intrusion of politics into the university was "lamentable," and that the university "must be separated from politics."12 He personally had added article $47 \mathrm{~b}$ to the new law, stating that "full professors cannot simultaneously teach and engage in any other form of public activity." Article 47 provided that professors "cannot defend interests which may oppose, compete, or collide with those of the Nation."

The result of the new law was that only Peronist professors could teach at Argentine universities. Within three months of the original intervention, 1,250 professors had resigned, and by 1953 there had been a ninety per cent turnover. Bernardo Houssay, I947 Nobel Prize Winner, had resigned under the accusation of "incompetence." 13

The extent of Peronist intervention and control of the universities was revealed after his overthrow. The writer of this article was allowed to participate, in October 1955, in the study carried out by a special commission of the Lonardi provisional government of the files of the Ministry of Education and its dependent organs. This study revealed the existence of a "strictly secret" administrative police organization, the "Servicio de Enlace y Coordinacion," as it was euphemistically named. Receiving information from such disparate sources as the Peronist labor union, the military intelligence service, the police, both branches of the Peronist

${ }^{21}$ Ley Universitaria, Ley 13031 of Sept. 26, 1947, 22 Archivos DE LA UNIVERsidad de Buenos Airzs. 42I-43 (July-Dec. 1947).

${ }_{12}$ Discurso del Excelentisimo Senor Presidente de la Nacion, General de Brigada Juan Peron, Acto de Promulgacion de la Ley Universitaria 20-2I (Universidad de Buenos Aires, Departmento de Accion Social Universitaria, r947).

${ }^{13}$ Cf. Lattendorf, Doce Años de Dictadura en la Universidad, in FUBA, In Reforma Universitaran, op. cit. supra note 2, at $187-95$. 
party, and a large number of informers within the universities, forty-eight full-time employees developed an information system which covered every phase of Argentine university life. Essential information was maintained in this office on every one of Argentina's roo,000 professors and students. The effort to control the university had led to the development of complete personal folders on 70,000 of these students and professors. These folders contained copies of personal letters, reports from informers on friendships, conversations, political beliefs, and other related information. There was abundant evidence of the use of unsubstantiated information against individuals, and the development of a system whereby the rector of the university could be ordered to automatically dismiss students or professors. ${ }^{14}$

After the fall of Peron, the universities were briefly taken over by student organizations, who carried out a "counterpurge."15 At the end of 1957, the Aramburu government re-established autonomy, giving the right of election of the rector to the University Assembly. The political pre-eminence of the university meant, however, that the political storm was largely passed on into the university itself. During the elections at the University of Buenos Aires in November and December 1962 , there was much heat and occasional violence. When the electoral process came to its culmination in the vote for rector, a secret ballot was called for in the Assembly, since "extra-university organisms of considerable power had operated in a rather open fashion" in an attempt to influence the election. ${ }^{16}$ The establishment of autonomy had thus done much to free the university, but it had by no means eliminated the play of politics.

Neither of these episodes is unique. Although it is unlikely that the Peronist. intervention has been matched fully, there have been similar situations reported in Paraguay, the Dominican Republic, and elsewhere. ${ }^{17}$ The recent Cuban situation is probably not very different, although as will be seen below, its dynamics were initially different.

The efforts to seize control of universities by governments have often met with failure. Batista was never able to fully control the Cuban universities. Even Peron could not prevent the students from remaining organized underground against him. One of the aspects of university autonomy which has most often stayed the hand of those interested in intervening is the retention of the medieval concept of the immunity of the university. One current formulation of this concept reads: "The

\footnotetext{
${ }^{14} \mathrm{I}$ have been unable to get a printed report, if any, of the investigation. The above account is from my notes at the time.

${ }^{16}$ An interesting account in English is Delmas, The Revolution in Argentina's Universities, The Reporter, Jan. I2, 1956, pp. 26-30. An extremely good account of life at the University of Buenos Aires. following the return of Autonomy will be found in Kalman H. Silvert, Other Peoples' Classrooms, in The Conflict Soctety: Reaction and Revolution in Latin America (ig62).

${ }^{10}$ La Nacion (Buenos Aires), Dec. 8, Ig62, p. I.

${ }^{17}$ The best single source, though biased from the student side, for such events, including reports. on Venezuela, the Dominican Republic, Paraguay, Nicaragua and Cuba, is the RIC Yearbook, published by the Research and Information Commission of COSEC (see supra note 2). One of the more common means used is to have young persons employed by the security departments register in the universities. as students.
} 
university grounds are inviolable. The maintenance of order within them falls within the competence and responsibility of the university authorities." ${ }^{18}$ This means in practice that national police and military units cannot enter the grounds without the express authorization of the rector, who is generally loath to grant it. This concept, meant to assist the isolation of the university from partisan pressures and politics, has actually often increased them. The key element is the respect for political and civil liberties in the country at large. When these are respected, the immunity of the university takes on little importance. But when they are not, the university becomes the haven for the opposition, which uses it as a guarantee against persecution. This use of the university may not be physical in the sense of nonstudents occupying the grounds: there is always a student group ready to pronounce itself for freedom according to the definition desired by some outside group which may offer encouragement or financial support. Two aspects of this problem should be noted. The first is that although the students are usually supporting an outside group, and sometimes initiating opposition to a government, they are usually doing so voluntarily, out of the rebelliousness of youth. They are not normally the tools in any direct sense of outside groups, although they can often be exploited. The second is that although the question of university defense of unpopular politics is easiest to understand under some form of doctrinaire dictatorship, it has relevance under most present Latin American governments. There is little consensus on political values in Latin America, partly because of the rapid process of change which is taking place. Any government thus finds itself in a position of being bitterly opposed by some group, usually originating or finding an echo in the university. The desire to put pressure on the university is thus nearly always present. It is also very difficult to draw the line between justified and unjustified interventions, especially since any intervention will be a violation of autonomy. ${ }^{10}$

Autonomy, one of the chief original demands of the reform movement, has often been curtailed in the name of reform. This is one of the inherent tensions and contradictions in the place of the university in society. To function properly, goes the reformist conception, the university must be autonomous. But the function of the university is not thereby exhausted: it has a role to play in society, a role which is inherent in the education it gives and in the nature of the groups it educates. "If the University Reform were only a university reform, it would do no good, since a university cannot do any good in a country sunk in misery and vassallage."20

One attack on autonomy in the name of reform, which failed after a prolonged

${ }^{18}$ Title I, article 6, of the Venezuelean University Law of Dec. 5, 1958. The law is available as an appendix to the study by Focion Febres Cordero, Autonomia Universitaria (Caracas, Universidad Central, r959). Cordero's companion book, Reforma Universitaria (1960), completes one professor's massively documented account of the problem in Venezuela.

${ }^{20}$ The best account of the student viewpoint is given in The Student Strugcle in South Americh, Report of the International Student Conference Delegation, COSEC (1958), which is also an excellent account of the student reform movement in South America.

${ }^{20}$ The author of this rather extreme but clear statement is Alberto Ciria, Los Estudiantes y la Politica en America Latina, in FUBA, La Reforma Universitaria, igr8-1958, op. cit. supra note 2, at 365 . 
and violent student-professor strike, took place in Bolivia, after the national trade union (COB), at its Spring I955 national congress, called for the "centralization in the hands of the state of the systems and plans of education of the universities" because they were "creating a class hostile to the interests of the revolution."21 This effort failed because the government bowed to the united front of opposition from the universities, and because the demand for reform, which it would otherwise have tolerated, came from outside the university.

The most striking case, however, of the destruction of autonomy in the name of reform from within the university took place in Cuba in rg6o. The Cordoba manifesto had seen the participation of students in the running of the university as a means of reforming the universities without curbing their autonomy. On July I, $\mathrm{r} g 60$, the student federation at the University of Havana (FEU), then presided over by Rolando Cubela, a medical student who had attained the rank of major in the Escambray, issued a long manifesto complaining that ${ }^{22}$

[the] University of Havana slumbers, ineffective, sterile, bureaucratic, insensible, as though it were not a part of the Republic, like a retrograde and cursed feudum in the heart of the liberated land.

In terms reminiscent of the Cordoba manifesto, the FEU declared "education in our university is a fraud ... scientific inquiry is ignored . . . libraries are notable in their absence. . . ." It condemned the "sterile memorization of single texts" and placed guilt squarely on the faculty and administration, and demanded a "true university reform." To attain this end, it proposed a I7-point program, including the "expulsion of incompetent, immoral, grafting, and counter-revolutionary professors."

When the university council, on which there was no student representation, refused to meet the FEU demands, invoking the autonomy, the FEU replied that, ... you are the same ones-the names do not matter-who have been running the university for 30 years, and we have now understood that to make the University Reform with you would make as much sense as to have the Agrarian Reform implemented by those who would be hurt by it. You are the great landowners of culture....23

A new governing junta of the university, composed of four students and four professors, constituted under the threat of student violence, declared nine days later that university autonomy should "be used not as a counter-revolutionary wall, but as a vehicle to promote the unity of the government, the university, and the revolution." 24 What followed was entirely reminiscent of Peron. ${ }^{25}$

\footnotetext{
${ }^{21}$ For a brilliant defense of university autonomy by a revolutionary rector, see ARTURo URQUIDI Morales, Labor Universitaria 95-II3 (Cochabamba, Bolivia, Imprenta de la Universidad, I955) (1958).

${ }^{22}$ La Universidad de la Habana Hacta una Neuva Etapa 2 (ig6o).

${ }^{23} I d$. at 2I-22.

24 Id. at 30 .

${ }^{25}$ With the slight difference that many of Peron's acts were to the chant of "zapatillos, si; Universidad, no" (shoes yes, University no), while the student federation at the University of Havana (FEU) said it was trying to "convert the entire island into a school."
} 
III

Student participation in the government of the university is deeply rooted in the Latin American tradition. Its origin is to be found in the thirteenth century at the universities of Bologna and Salamanca, and the development of the self-ruling universitas magistrorum et scholarium. The re-institution of student (and graduate) participation was one of the chief demands of the reform movement, and although it has not been the panacea its original proponents expected, it has had an important effect on the functioning of the typical national university. ${ }^{26}$

To the outsider, especially at first acquaintance, this impact has been generally contrary to the development of academic freedom as it is understood elsewhere in the world. Student pressure has been weighted heavily toward such things as student participation in the naming of professors, periodic competitions for professorial chairs (no tenure), and optional class attendance. The sources of these demands, at least one of which is diametrically opposed to the United States tradition of academic freedom, must be sought in three main factors.

The first is in the position of the students of the typical Latin American university. They distinguish themselves sharply from their United States counterparts in social position, age, and self-conception. Most students in Latin America, although they may come from middle-class families, have to work to support themselves through school. Often they find full time employment, frequently in the government bureaucracy. One of the results is that they are both older and less likely to look upon themselves as apprentices or role-transients. They are simultaneously students and citizens, very much like some graduate students in the United States. ${ }^{27}$ To this

${ }^{20}$ The exact pattern of the integration of students into the government of the universities varies considerably. In Panama, the situation is as follows: The students are represented by their Federation (UEU). The UEU's major organ, the Directorio Estudiantil, is composed of sixty members, ten from each of the University's six faculties. This organ meets monthly and determines student policy. The academic policy of the University is determined by the Consejo General Universitario, which also elects the Rector. This body is composed of approximately rro professors and twelve students. Administrative and financial matters are dealt with by the Junta Administrativa, which has fourtecn members, the Rector of the University, the Deans of each faculty, and six students, one from each faculty, and a representative of the Ministry of Education. In addition, the university has a separate board for each faculty, made up of the professors of the faculty and two students. The total of students sitting on the governing boards of the university is thus thirty. Each student has an alternate, which gives us a total of sixty students participating directly in the governing of the university. These sixty are the same sixty who sit on the Directorate of the UEU. The students have taken the responsibility well, I was told by the Rector in 1956, and he feels that a number of improvements are the direct result of the student intervention. Faculty and professional discussions of these matters, together with the statutes of many of the universities, will be found in Universidades, the publication of the Union de Universidades de America Latina.

${ }^{27}$ Or, one might be tempted to say, some of the younger generation of Negroes in the United States. But the situation is still different. Here is an excerpt from a letter from an officer of the FUA during the struggle against Peron: "We have learned with pleasure that at International Student Conferences they spoke about student lodgings, student travel, and so on, because this shows us the high level attained [in the United States and Western Europe], but as you understand, this did not have the least bit of practical importance for us. The practical thing for us was to live hidden from the political police, to print our clandestine newspapers, to have our meetings broken up, to be expelled from the universities, to be arrested ...." (letter from Gerardo Andujar). 
self-conception is added their political importance, and their general tendency to manifest sharp generational differences with their elders: they have yet to mature and grow indifferent to the problems which surround them. ${ }^{28}$

The second factor concerns the nature of the teaching staff. Although there are some notable exceptions and rapid improvements are being made almost everywhere, few teaching positions at Latin American universities are full time, and fewer still are sufficiently remunerative to enable the professor to survive without additional employment. ${ }^{29}$ As a result teachers are often ill-prepared, have little opportunity to keep up with their field of knowledge, and often tend to regard teaching at the university as a prestigeful hobby. ${ }^{30}$

Finally, there is the political factor once again. This affects both students and professors. The students are fearful of indoctrination or of expulsion from the university for engaging in activities which they consider to be either defensive or proper by right. The professors are often political appointees, or fearful of being replaced by political appointees.

The students urge optional attendance to give them the opportunity to boycott poor professors and to give them the chance to go on strike without fearing expulsion. They oppose tenure so as to be able to replace poor professors, or at least have the chance to try to do so, at regular intervals.

There is universal agreement that the situation is not ideal. Judgments made of the situation depend largely on expectations of alternatives.

\section{IV}

Several factors combine to suggest that although tensions and conflicts will remain, there will be an increasing trend away from the political university in Latin America. One of these is the erosion of the conservative and traditional insistence that the universities should have nothing to do with national life. Reformers have thus begun to consider the problem of how the university can best serve the nation, rather than the emotional question of whether it should do so. In Argentina since 1956, and in Mexico since somewhat earlier, the idea that the university can best serve the country by providing competent professionals trained in relevant fields has

${ }^{38}$ One of the fascinating questions still to be looked at by social scientists is: What happens to the university radicals when they graduate? The reform movement as a whole has been extremely radical since its inception.

${ }^{20}$ Venezuela, which pays its professors on a level comparable to most United States universities, is the major exception. In Bolivia, at the time of the 1955 crisis, professors who taught six hours a week were paid $\$ 8.00$ a month. In Argentina, the salary for a full-time full professor may reach as high as $\$ 500$ a month, but assistants fall to as low as $\$ 20$.

${ }^{80}$ The recent growth of research institutes in the more advanced countries, often with U.S. foundation help, should help resolve these problems in the long run. One of the reasons why national systems of higher education have not developed more fully has been due to the already mentioned absence of resources, often abetted by the fact that families with money could send their sons to the United States and Europe for education. In some of the smaller countries, in particular, these numbers have recently reached 15 to $25 \%$ of all students. 
been gaining ground. ${ }^{31}$ Another element of change is to be found in the expansion of systems of higher education and the changes introduced by the founding of new private universities and research institutes. This expansion of education and improvement of research and teaching is meeting one of the major demands of the reformers, and weakening the drive of students to participate in the educational process. ${ }^{32}$ Finally, the increase in the number of institutions makes life easier for the professors also: a professor unemployable for political reasons at one university may find employment at another. There is more room to breathe. A last important factor in the depoliticization of the university is the opportunity of graduates to find jobs in new government and private agencies working on development.

But the political tradition, and many of the problems which gave rise to it, remains with us. University autonomy finds three kinds of supporters: those who see it as the indispensable precondition of the educational process; those who are satisfied with the university the way it is, and oppose changes in the name of autonomy; and, finally, those who see autonomy as a means of obtaining a platform from which to attack the government in power. University reform similarly finds three main types of supporters: those who believe substantive educational changes are necessary within the university; those who want to increase government control over the university; and lastly those who, though weak in the university, want to strengthen their position in it as a preliminary step to social reform.

This characterization implies that there is only one group almost likely to always support both autonomy and reform: the professional educator. But it also implies that more professionals are not in themselves enough to solve the problem of the political university. That problem will be reduced to a manageable level only when some form of broad political and social consensus emerges in Latin America.

\footnotetext{
${ }^{31}$ The question was particularly raised by Risieri Frondizi while Rector of the University of Buenos Aires (1957-1962). Rector Chavez at the National Autonomous University of Mexico has recently strengthened the already strong Mexican tendency in this direction. See Frondizi, La Universidad y sus Misiones, Comentario, Oct.-Nov.-Dec. 1956, pp. 3-9 ff. (reprinted in both COSEC, LA REForma UNIversitaria en AMerica LAtins, and FUBA, LA Reforma Universitaria igr8-1958, op. cit. sitpra note 2).

${ }^{82} \mathrm{~A}$ number of these phenomena have already been at work in Mexico for some time.
} 